\title{
An Innovative Multi-Disciplinary Active Learning Task Towards OBE-A Case Study
}

\author{
Uma Rao $K^{1}$, Prema $\mathbf{V}^{\mathbf{2}}$ \\ RV College of Engineering, Bangalore \\ ${ }^{1}$ umaraok@rvce.edu.in \\ ${ }^{2}$ premav@rvce.edu.in
}

\begin{abstract}
The main objective of active learning is to shift the responsibility of learning on the learner wherein the teacher only acts as a facilitator. This is easier said than done, since the system has to facilitate this learning process. Active learning strategies are an integral part of Outcome Based Education, as successful completion of a task by the student, implies the effectiveness of the system and curriculum to facilitate the learning. Engineering education in India is slowly moving towards Outcome Based Education, with autonomous colleges, which have flexibility of curriculum, taking the lead. This paper presents the description, objectives, student survey and outcomes of an active learning task, called 'Self-study' and introduced in the curriculum of undergraduate engineering students, to enhance multidisciplinary learning in students and meet various Graduate Attributes.
\end{abstract}

Keywords: Active Learning, OBE, Self-study, graduate attributes

\section{Introduction}

India is in the process of a huge transformation in higher education in general and technical education in particular $[1,2]$. India has one of the largest number of universities and engineering colleges. However, the structure of Indian institutions has remained conservative, until recently. Earlier, colleges had to be affiliated to universities approved by the University Grants Commission (UGC) the apex body for overseeing the higher education in India. All colleges affiliated to a particular university had to strictly follow the syllabus of the university and had no flexibility in the curriculum. Slowly, institutions with infrastructure and existing for a long time, were given the status of deemed universities and operated as per guidelines given by the UGC [3]. These deemed universities had the freedom to prescribe their own norms for admissions, tuition fees, set their evaluation procedures and develop

\footnotetext{
Dr. Uma Rao K ${ }^{1}$

${ }^{1}$ EEE, R V College of Engg, Bangalore

${ }^{1}$ umaraok@rvce.edu.in
}

curriculum independently.

Another set of institutions which were over 10 years old, could become autonomous even though they are affiliated to a university. These colleges had to adhere to the admission and tuition fee structure prescribed by the affiliating university. However, autonomous colleges enjoy complete autonomy as far as their syllabus and curriculum is concerned, at the same time adhering to the general norms of the university as to the number of credits for a course, infrastructure requirements etc. In line with these changes, accreditation norms in India became more stringent and there was a thrust of awareness on Outcome Based Education, to enable institutions to meet international accreditation standards. Hence, institutions which gained autonomy, introduced a number of changes in the curriculum. Some of the major changes were increase in laboratory courses, mini-projects in lower semesters, more emphasis on the final semester project work [4-5], increase in number of elective courses as opposed to core courses, interdisciplinary electives, electives in tune with industry requirements, evaluation becoming more objective than subjective, continuous assessment of students, introduction of more courses in humanities and finance, emphasis on communication skills and team work and seminars to improve the presentation skills. These changes have brought about a noticeable change in the outcome of the engineering degree when compared to a decade ago[6-7].

Different institutions give different names to a component in the curriculum where a student is expected to learn a topic by himself/herself with the teacher only facilitating in case of need[8-9]. This component goes by the names, 'Self Learning Exercise (SLE)', 'Self Learning Topic', 'Self Study' etc. The end result of the component could be a presentation made by the student, a team paper, a simple project or even a quiz. In this paper the 'Self-study' component introduced as an activity in an autonomous college is discussed. It was envisaged to be an active learning task with the whole class participating in the task and sharing information, with teachers acting to bridge gaps in any understanding of the topics. Details of the task, the objectives, some sample topics, student survey and the final outcome are discussed in the following sections. The 
class considered for the study are first semester undergraduate students of Electrical Engineering.

\section{Description of the task}

This task is primarily meant for the entire class to participate. Normally the class strength is 60 . The details of the task are as follows:

1. The students of a class of 60 are given two topics, which are broad based and have scope for a number of sub-topics to be investigated by the students. The topics should relate to the subjects studied by the students but not dealt with in their regular curriculum. Some typical topics given were 'Home automation', 'Adaptive controls for industrial processes', 'Bio medical instrumentation', ' Assistive technologies' etc. . In the current case study the topics given were (i) 3-D printing and (ii) hybrid power systems.

2. The class is then divided into two groups of 30 each. Each group is given one of the topics.

3. Each student selects a subtopic under the main topic. For example :

- Under 3-D printing some of the topics chosen were

i. A vending machine with a built-in delta $3 \mathrm{D}$ printer.

ii. $3 \mathrm{D}$ printing by electron beam freeform fabrication

iii. 3D printed bicycle

iv. Maximization of colours in 3D printing

v. First combat aircraft with 3D printed parts

vi. $3 \mathrm{D}$ printing in textiles

vii. Vitamin boosts in $3 \mathrm{D}$ printing of medical implants

viii. $3 \mathrm{D}$ printing in micro-dental labs

ix. $\quad 3 \mathrm{D}$ printing of metals

- Under hybrid power systems some of the topics chosen were

i. Plug-in hybrids

ii. Solar and mini-hydel hybrid system

iii. Battery recharging

iv. Hybrid solar cell

v. Maximum power tracking

vi. Site conditions for hybrid PV plants

vii. Challenges in hybrid power systems using renewable energies

viii. Disposal of solar PV waste

ix. Next generation PV cells

4. Once the student chooses the topic, the student has to collect information about it, and then review the application of four subjects of the current semester in the topic. In the case study, the students learn Basic Electronics, Mathematics, Basics of Mechanical Engineering and Computer Programming in the first semester. So a student has to clearly demonstrate the application and use of these four subjects in the topic of his/her choice. This helps the student to understand the need to study different subjects and how to integrate them in an application. Let us consider an example. In the topic on ' $3 \mathrm{D}$ printing of metals' a student came up with the following applications of different subjects

- Use of software Slicer to create G-codes to give instructions tailored to a particular printer. This gives the role of computer programming.

- Electronic circuitry and micro controllers for control, to demonstrate the role of electronics

- Elementary mechanical design of the printer, to demonstrate the need to study basic mechanical engineering

- Representation of an n-dimensional object as spectrum of layers of $\mathrm{n}-1$ dimensions and mathematical computations to illustrate the role of mathematics.

5. The student then has to also analyze the problems in the topic under study and come up with suitable solutions; the level of the solution would depend on the semester of study.

6. The students make a presentation of around 10 minutes, in two phases. In the first phase the student presents the basic premise of the topic chosen, and a brief idea about the role of each of the subjects in it. In the second phase the student presents it in depth. The presentation is made using power point, to the whole class and the evaluators. Higher semester students make a simulation model, a mathematical model or a physical model and demonstrate it.

7. At the end of the semester, the student makes a written report of the topic.

\section{Objectives of the task}

One of the objectives when the activity was first introduced was to update the knowledge of the class on a trending topic. Since a student cannot go through different aspects of a topic as time involved would be very large, this activity was viewed as a platform for each student to collect information on a different sub-topic, understand it, and share the knowledge with the rest of the class, so that the entire class can gain mastery over various aspects of a topic. Apart from this, the task was also envisaged to enhance many skills in the students, which would help in attaining many of the Graduate Attributes (GA) as stipulated by the National Board of Accreditation (NBA) in India. These are similar to the GAs laid down by ABET. The objective of the task was to develop different skills and their mapping to the Graduate Attributes is as follows:

1. Enable the student to view a particular engineering topic from different perspectives and analyse the role of different subjects learnt (GA1 -Application of Engineering Knowledge).

2. The student analyses the problem from different angles. He/she also develops the skill to integrate multi-disciplinary subjects into one topic (GA2Problem solving).

3. The communication skills of the student is greatly enhanced as also the ability to present without fear, in front of an audience (GA10-communication skills )

4. Learn usage of latest software for presentation and simulation(GA5-Modern tool usage) 
5. Analyse the problem for issues of safety, environmental effects and sustainability (GA6 and GA7-Environment and sustainability)

6. Since the complete learning is done by the student the task is expected to promote the urge to indulge in learning (GA12-Life-long learning).

Thus it can be seen that the activity addresses multiple graduate attributes.

\section{Role of the teacher}

All the teachers teaching the subjects in the semester are involved in the activity. The teacher introduces the concept to the students and also clearly explains the utility of the task, to motivate students to actively participate in the activity. The role of the teacher is also to explain the topics given to the class and briefly mention some of the subtopics under each. This will give the student an insight into the topic and help the student in choosing any sub-topic of his/her choice. If any student expresses inability to choose a sub-topic the teacher steps in and helps the student to select a topic. If the student is unable to find material for preparation, the teacher helps the student in getting the material. Any doubts raised by the class during the presentations are clarified by the teacher. After the completion of all presentations, the teachers share their inputs with the students and summarize the major highlights of the topic. Finally the teachers evaluate the students. Every teacher tests the student in her/his subject. For example an electronics teacher would assess whether the student has understood the role of electronics in the topic under consideration and so on.

\section{Assessment and evaluation}

The student is evaluated based on the following points.

1. Choice of sub-topic and its analysis

2. Communication skill

3. Quality of presentations (Visual, sequence, flow etc. )

4. Treatment of fundamental concepts and application of the different subjects

5. Regularity in attending all sessions

6. Timely submission of report

7. Quality of the report

8. Ability to ask and also answer questions

The rubrics for the evaluation is as shown in Table:1The weightage given to this activity is $20 \%$ for the continuous evaluation assessment, for each of the subjects.. The total task is given 4 credits.

\section{Feedback}

The following feedback form was given to the students to assess the problems in the task execution from a student's perspective. The feedback questions were framed to assess the utility to the student, the role of the teacher, whether the students want to continue the task in higher semesters and the benefit of knowledge sharing with other students of the class. The feedback form is shown in Table 2.
Table 1.Evaluation Rubrics Level of Achievement

\begin{tabular}{|l|c|c|c|c|c|c|}
\hline \multicolumn{7}{|c|}{ Level of Achievement } \\
\hline a & $\begin{array}{c}\text { Criteria } \\
\begin{array}{c}\text { Linking } \\
\text { the } \\
\text { topic to } \\
\text { various } \\
\text { courses }\end{array}\end{array}$ & Excellent & Good & Average & Poor & $\begin{array}{c}\text { Max } \\
\text { Score }\end{array}$ \\
\hline b & $\begin{array}{c}\text { Underst } \\
\text { anding } \\
\text { the } \\
\text { topic } \\
\text { and } \\
\text { approac } \\
\text { h }\end{array}$ & $25-30$ & $20-24$ & $10-19$ & $1-9$ & 25 \\
\hline c & $\begin{array}{c}\text { Commu } \\
\text { nication } \\
\text { Skills }\end{array}$ & $9-10$ & $7-8$ & $5-6$ & $1-4$ & 10 \\
\hline d & $\begin{array}{c}\text { Present } \\
\text { ation of } \\
\text { slides }\end{array}$ & $9-10$ & $7-8$ & $5-6$ & $1-4$ & 10 \\
\hline e & Report & $16-20$ & $10-15$ & $6-10$ & $1-5$ & 20 \\
\hline f & $\begin{array}{c}\text { Questio } \\
\text { n \& } \\
\text { Answer }\end{array}$ & $4-5$ & 3 & 2 & 1 & 5 \\
\hline g & $\begin{array}{c}\text { Attenda } \\
\text { nce }\end{array}$ & $4-5$ & 3 & 2 & 1 & 5 \\
\hline
\end{tabular}

Table 2.Feedback form for Self -Study Topics : 1. 3-D printing.2. Hybrid power systems Rating : 1 -poor ; 2- fair; 3- good; 4 - Excellent

\begin{tabular}{|c|c|c|}
\hline $\begin{array}{c}\text { Sl } \\
\text { NO }\end{array}$ & Questions & Rating \\
\hline 1. & $\begin{array}{c}\text { Were you given a briefing about } \\
\text { the concept of self study, by the } \\
\text { teacher? }\end{array}$ & \\
\hline 2. & $\begin{array}{c}\text { Do you think it initiated you } \\
\text { into self-learning? }\end{array}$ & \\
\hline 3. & $\begin{array}{c}\text { Did you find sufficient material } \\
\text { to present your topic? }\end{array}$ & \\
\hline 4. & $\begin{array}{c}\text { Did it help you in looking at a } \\
\text { complex problem in simpler } \\
\text { terms by breaking it into } \\
\text { smaller sub-topics? }\end{array}$ & \\
\hline 5 & $\begin{array}{c}\text { Did it enhance your usage of } \\
\text { tools for presentation? }\end{array}$ & \\
\hline 6. & $\begin{array}{c}\text { Do you think it enhanced your } \\
\text { communication skills? }\end{array}$ & \\
\hline 7. & $\begin{array}{c}\text { Did the activity help you to } \\
\text { improve your confidence ? }\end{array}$ & \\
\hline 8. & $\begin{array}{c}\text { Were you able to map the utility } \\
\text { of the subjects studied to the } \\
\text { self study topic? }\end{array}$ & \\
\hline 9. & $\begin{array}{c}\text { Did you get feedback from } \\
\text { teachers about how to improve } \\
\text { and did you see an }\end{array}$ & \\
\hline 10. & $\begin{array}{c}\text { Do you think self-study should } \\
\text { be continued from a perspective } \\
\text { of enhancing your capabilities? }\end{array}$ & \\
the group /yourself from phase \\
\end{tabular}$\quad$\begin{tabular}{l} 
\\
\hline
\end{tabular}




\section{Critical Evaluation of the feedback from students}

The achievement of objectives of the task was assessed from the feedback forms. A total of 42 respondents answered the questionnaire. The ratings and the inference drawn are tabulated in Table 3 .

Table 3: Critical evaluation of student feedback

\begin{tabular}{|c|c|c|c|}
\hline $\begin{array}{l}\text { Question } \\
\text { no }\end{array}$ & $\begin{array}{l}\text { Average } \\
\text { rating on a } \\
\text { score of } 4\end{array}$ & $\begin{array}{l}\text { Percentage } \\
\text { score }\end{array}$ & Observation/Remark \\
\hline 1. & 2.6 & $65 \%$ & $\begin{array}{l}\text { Teachers should spend more time in explaining the task and its objectives to } \\
\text { the class }\end{array}$ \\
\hline 2. & 3.4 & $85 \%$ & Activity has effectively driven the student to self-learning. \\
\hline 3. & 2.5 & $62.5 \%$ & $\begin{array}{l}\text { Many students were not satisfied with the material they could collect. The } \\
\text { teacher has to involve more in directing and helping the student to get good, } \\
\text { relevant and sufficient material. }\end{array}$ \\
\hline 4. & 2.5 & $62.5 \%$ & $\begin{array}{l}\text { The reason for a lower rating to this question could be because the class was } \\
\text { first semester UG. They have not yet been introduced to complex } \\
\text { engineering solutions. }\end{array}$ \\
\hline 5. & 3.6 & $90 \%$ & The students felt that their presentation skills were vastly enhanced. \\
\hline 6. & 3.7 & $92.5 \%$ & $\begin{array}{l}\text { Overwhelming majority of the students indicated an improvement in their } \\
\text { communication skills. }\end{array}$ \\
\hline 7. & 3.4 & $85 \%$ & $\begin{array}{l}\text { Since the students had to make presentations in front of the whole class and } \\
\text { the teachers, their confidence levels were boosted. }\end{array}$ \\
\hline 8. & 2.7 & $67.5 \%$ & $\begin{array}{c}\text { Some of the students were not able to effectively map the subjects and } \\
\text { integrate it to the topic. The teacher has to play a greater role in facilitating } \\
\text { this. }\end{array}$ \\
\hline 9. & 3.2 & $80 \%$ & Students were benefitted from the feedback received by the teachers. \\
\hline 10. & 3.7 & $92.5 \%$ & Students desire to continue with the task. \\
\hline
\end{tabular}

\section{Outcome}

In the present study the first semester undergraduate students of Electrical Engineering had to integrate the courses of Basic Electronics, Computer Programming, Basic mechanical engineering and mathematics, into the chosen topic of their study. On successful completion of the activity of 'self-study', the following outcomes were observed.

- The students showed a significant improvement in communication and presentation skills in the second phase of the work as compared to the first phase.

- Students who were extremely shy and scared of facing an audience in the first phase, were able to overcome their fear and present well in the second phase.

- A majority of the students were able to appreciate the need and role of different subjects introduced in a semester.

- Competition amongst the students was obvious and each of them tried to do an effective presentation

- Collectively the class felt that their learning skills, communication and presentation skills were enhanced and they expressed a desire to continue with the activity in the next semester.

- In the subsequent semester the class was given a topic of 'Home automation' and the performance drastically improved especially in terms of subject mapping and content. Further, many of the students developed a working model to demonstrate their ideas. This observation is important for it is indicative of a progressive enhancement of the ability of the students to self learning and integration of multi-disciplinary courses and their mapping in a given application.

\section{Conclusion}

In this paper a case study has been presented on the outcome of an active learning task to enhance the selflearning capability of the student, in an undergraduate electrical engineering course. The study reveals the need for an activity wherein the teachers facilitate a self-learning process in the students and also enable them to integrate different courses learnt in a semester in a practical application. The activity also enhanced communication skills, presentation skills, analytical and problem solving skills, along with an inculcation of a desire for life-long learning.

\section{References}

[1] BimanSen, "Development of Technical education in India and state policy-A historical perspective", Indian Journal of history of science, 24(4), 1980, pp 224-248

[2] Madhu Singh, "India's National Skills Development Policy and Implications for TVET and Lifelong Learning", The Future of Vocational Education and Training in a Changing World, Springer 2012, pp 179211, ISBN 978-3-531-18527-9

[3] Mahadevi. S. Banad and Mahadev. Talawar, "Impact of Globalization on Indian Technical Education System", chapter 5, New Knowledge in a New Era of Globalization, Intech Publications, ISBN 978-953-307501-3

[4] R. Hashim, M. Azizi , "Implementing Outcome Based Education Using Project Based Learning at University of Malaya", European Journal of Scientific Research ISSN 1450-216X, Vol.26, No.1 80-86, 2009.

[5] D. Padmashree, M. Vijayalakshmi and G.H. Joshi, "A novel approach to carrying out mini project in Computer Science \& Engineering", Engineering 
Education: Innovative Practices and Future Trends (AICERA), IEEE International Conference. 978-14673-2267-6, 2012.

[6] B. Kanmani and MallikharjunaBabu, 'Leveraging Technology in Outcome Based Education', International Conference on Transformations in Engineering Education, ICTIEE-2014, Hubli, January 16-18, 2014.

[7] K. N. Raja Rao, N. S. Narahari , C. BinduAshwini, "Emphasis on the Cognitive Framework in Teaching Learning Process in Engineering Education: An Empirical Overview", International Conference on Transformations in Engineering Education, Special Issue, January 2015

[8] P. E. Sreeram Ramakrishna, MudrikaKhandelwal, "Attributes of Engineers and Engineering Education for the 21st Century World", Volume 27, International Conference on Transformations in Engineering Education, Issue 4, July 2014

[9] N. Vijayakumar, V. N. Gaitonde, A. R. Lakkundi , H. K. Madhusudhana , G. JangaliSatish, "Experiential Learning in Metrology and Quality Engineering Course", International Conference on Transformations in Engineering Education, Volume 29, Issue 1, July 2015 